\title{
Potret Keterwakilan Politik Perempuan Anggota Legislatif di DPRD NTT pada Pemilu 2014
}

\author{
Audra Jovani \\ Universitas Kristen Indonesia
}

\begin{abstract}
Abstrak: Artikel ini mendeskripsikan mengenai potret perempuan anggota legislatif di DPRD Provinsi Nusa Tenggara Timur (NTT) yang terpilih dalam pemilihan umum legislatif tahun 2014. Dalam kerangka implementasi afirmative action (kuota 30 persen) mengenai keterwakilan perempuan di parlemen sudah dilakukan sejak tahun 2004, dan artikel ini ingin menjelaskan bagaimana keterwakilan perempuan NTT di lembaga legislatif dilihat dari latar belakang dan motivasi perempuan dalam mengikuti pemilu. Dengan menggunakan metode studi kasus dan analisis melacak proses, artikel ini berpendapat bahwa perempuan NTT yang berpartisipasi dalam pemilu 2014 mampu berkontribusi dalam mewujudkan keterwakilan perempuan di dalam partai politik dan parlemen, walaupun dalam perjalanannya, banyak menghadapi tantangan, baik internal maupun eksternal.
\end{abstract}

Kata Kunci: Keterwakilan, Legislatif, Partai Politik, Nusa Tenggara Timur

Abstract: This article describes about women legislative member in Provincial Parliament in Nusa Tenggara Timur, who elected in legislative election in 2014. On the frame of the implementation of women's representation in parliament that has been started since 2004 election, this article explains representation of NTT's women in parliament based on back ground and the motivation to participate in election. Using case study method and analysis with process tracing, this article argues that NTT's women who participated in election, have contributed to consummate women's representation into their political party and parliament. Even thought, NTT's women has been faced internal and external challenges.

Key Words: representation, legislative, political party, Nusa Tenggara Timur

Koresponden penulis:

Audra Jovani, Program Studi Ilmu Politik, Universitas Kristen Indonesia

Jl. Mayjen Sutoyo No. 2, Cawang, Jakarta Timur.

E-mail: audra.jovani@uki.ac.id 


\section{PENDAHULUAN}

Perempuan memiliki kebutuhan-kebutuhan khusus yang hanya dapat dipahami oleh perempuan. Kebutuhan-kebutuhan tersebut meliputi kesehatan reproduksi, masalah kesejahteraan keluarga, kepedulian kepada anak, kebutuhan manusia lanjut usia dan tuna daksa, serta isu-isu kekerasan seksual. Dalam banyak kasus keterlibatan perempuan dalam politik juga mampu memperbaiki masalah-masalah yang menghambat pembangunan. Studi yang dilakukan oleh Bank Dunia menunjukkan hubungan erat antara representasi perempuan dengan penurunan kasus korupsi (Yayasan Jurnal Perempuan 2004, 3).

Pengalaman di negara lain telah membuktikan bahwa keterwakilan perempuan di lembaga-lembaga politik pembuat keputusan memiliki andil sangat penting dalam mewujudkan kebijakan yang peduli pada kepentingan perempuan. Di Afrika Selatan keterwakilan perempuan di parlemen telah memainkan peranan penting dalam mempengaruhi kinerja berbagai departemen pemerintah, khususnya untuk proyekproyek yang berkaitan dengan kepentingan perempuan, seperti proyek pengairan, kehakiman, pemerintahan lokal, perdagangan dan perindustrian. Pemerintah membentuk seksi urusan gender di masing-masing departemen yang bekerja sama dengan Kantor Status Perempuan. Departemen-departemen pemerintah juga diwajibkan memprioritaskan program untuk memenuhi kebutuhan masyarakat, khususnya perempuan. Berkat perjuangan perempuan di Parlemen Afrika Selatan, pemerintah telah melakukan program-program pembangunan untuk rakyat miskin dan perempuan, antara lain pembangunan klinik-klinik kesehatan di pedesaan, perbaikan sekolah, penyediaan makanan bagi anak-anak sekolah, perawatan kesehatan untuk ibu hamil dan subsidi perumahan (Manzini 2002, 207). 
Secara normatif keberadaan perempuan di parlemen diharapkan bisa mempengaruhi kinerja lembaga legislatif sehingga lebih berpihak pada kepentingan perempuan. Upaya ini menurut Lovenduski dan Karam $(2002,159)$ dapat dilakukan dengan empat cara, yaitu:

Pertama, menyangkut bidang institusional atau prosedural, yaitu membuat parlemen lebih ramah kepada perempuan melalui langkah-langkah yang dapat menunjukkan kepedulian gender dan menghasilkan peraturan-peraturan yang lebih ramah bagi perempuan.

Kedua, berkenaan dengan representasinya. Artinya jaminan keberlanjutan dan peningkatan akses perempuan ke parlemen dengan mendorong dan mendukung kandidat-kandidat perempuan lain untuk berjuang masuk menjadi anggota parlemen, mengupayakan agar anggota perempuan mendapat posisi penting di parlemen, mengubah UU Pemilu dan kampanye, serta mengajukan legislasi kesetaraan jenis kelamin.

Ketiga, memberi dampak atau pengaruh terhadap keluaran (output). Hal ini berkaitan dengan upaya melakukan "feminisasi" legislasi dengan memastikan bahwa semua perundang-undangan atau semua produk kebijakan yang dibuat oleh lembaga legislatif benar-benar mempertimbangkan kepentingan dan kebutuhan perempuan (gender sensitive).

Keempat, mengubah wacana, yaitu menjadikan perspektif perempuan dalam perdebatan di parlemen sebagai suatu hal yang wajar dan mendorong perubahan sikap publik terhadap perempuan. Upaya ini dapat didukung oleh peran media massa dan publik, sehingga dapat meningkatkan kapasitas anggota legislatif perempuan dalam debat publik dan meningkatkan kepedulian mereka pada isu-isu perempuan.

Namun demikian, upaya perempuan untuk menyuarakan isu perempuan dan memperjuangan kepentingan perempuan di parlemen seringkali harus menghadapi kendala. Menurut Budi Santi $(2001,33)$ perempuan di parlemen sering terjebak dalam friksi antara kepentingan partai dengan kepentingan perempuan. Kepentingan partai 
yang kental dengan nuansa maskulinitas terkadang berbanding terbalik dengan kepentingan perempuan. Mau tidak mau perempuan anggota parlemen yang mempunyai ikatan lebih kuat dengan partai akan lebih memperjuangkan kepentingan partai. Isu-isu perempuan seringkali dianggap terlalu mengada-gada dan upaya memperjuangkan isu perempuan seringkali dianggap sebagai tindakan yang diskriminatif karena terlalu mementingkan kepentingan perempuan.

Akhirnya representasi perempuan menjadi sulit dijadikan tolok ukur peningkatan partisipasi politik perempuan yang tidak hanya terkait seberapa banyak perempuan menduduki posisi di lembaga-lembaga politik. Partisipasi politik perempuan perlu diperkuat dengan memperbaiki kinerja, kualitas dan keberhasilan perempuan dalam berpolitik, mengkaji dampak yang ditimbulkan dari partisipasi perempuan dalam sistem politik, memonitor perkembangan agenda politik dan memantau isu-isu yang muncul seiring dengan keterlibatan perempuan dalam politik (Seda 2002, 21).

Dalam Undang Undang Nomor 8 Tahun 2012 tentang Pemilihan Umum Anggota DPR, DPD dan DPRD Pasal 55 dan Pasal 56 ayat 2 jelas tertulis bahwa peserta pemilu harus melibatkan keterwakilan perempuan paling sedikit 30 persen dan dalam daftar bakal calon harus terdapat sekurang-kurangnya 1 calon perempuan. Hal ini juga terdapat dalam Undang Undang Nomor 2 Tahun 2011 tentang Perubahan Atas UU No. 2 Tahun 2008 tentang Partai Politik Pasal 2 ayat 2 dan ayat 5, 29 ayat 1a yang mewajibkan partai politik melibatkan perempuan sebanyak 30 persen. Ini sudah menunjukan keseriusan pemerintah dalam meningkatkan keterwakilan perempuan di dalam pemerintahan baik di tingkat nasional maupun lokal, namun keterwakilan perempuan pada Pemilu DPR 2014 mengalami penurunan sebesar 2 persen dari sebelumnya 19 persen pada Pemilu 2009 menjadi 17\% pada Pemilu 2014. 
Keterwakilan perempuan di parlemen pada 2009 dan 2014 dapat dilihat pada Tabel 1 di bawah ini:

Tabel 1. Anggota Legistatif DPR RI Tahun 2009 dan Tahun 2014

\begin{tabular}{|l|c|c|c|c|c|c|}
\hline \multirow{2}{*}{ Partai Politik } & \multicolumn{3}{|c|}{ Tahun 2009 } & \multicolumn{3}{c|}{ Tahun 2014 } \\
\cline { 2 - 7 } & Perempuan & $\begin{array}{c}\text { Laki- } \\
\text { laki }\end{array}$ & Jumlah & Perempuan & $\begin{array}{c}\text { Laki- } \\
\text { laki }\end{array}$ & Jumlah \\
\hline PDIP & 17 & 77 & 94 & 21 & 88 & 109 \\
\hline Golkar & 18 & 88 & 106 & 16 & 75 & 91 \\
\hline Gerindra & 4 & 22 & 26 & 11 & 62 & 73 \\
\hline Demokrat & 35 & 114 & 149 & 13 & 48 & 61 \\
\hline PAN & 7 & 39 & 46 & 9 & 40 & 49 \\
\hline PKB & 7 & 21 & 28 & 10 & 37 & 47 \\
\hline PKS & 3 & 54 & 57 & 1 & 39 & 40 \\
\hline PPP & 5 & 33 & 38 & 10 & 29 & 39 \\
\hline Nasdem & - & - & - & 4 & 31 & 35 \\
\hline Hanura & 4 & 12 & 16 & 2 & 14 & 16 \\
\hline Total & 100 & 460 & 560 & 97 & 463 & 560 \\
\hline
\end{tabular}

Sumber: diolah dari www.kpu.go.id

Dalam Tabel 1 terlihat bahwa jumlah perempuan di DPR mengalami penurunan pada 2009 jumlah perempuan sebanyak 100 sedangkan pada 2014 sebanyak 97. Partai politik yang caleg perempuan mengalami peningkatkan adalah PDIP, Partai Gerindra, PAN, PKB, PPP sedangkan Partai Nasdem sebagai partai baru memiliki tiga caleg perempuan di DPR. Yang mengalami penurunan adalah Partai Golkar, Partai Demokrat, PAN, PKS dan Partai Hanura. 
Tabel 2. Anggota Legistatif Perempuan DPR RI Tahun 2014 berdasarkan Provinsi

\begin{tabular}{|c|l|c|c|l|c|}
\hline No & \multicolumn{1}{|c|}{ Provinsi } & Jumlah & No & Provinsi & Jumlah \\
\hline 1 & Aceh & - & 18 & Nusa Tenggara Barat & 1 \\
\hline 2 & Sumatera Utara & 3 & 19 & Nusa Tenggara Timur & - \\
\hline 3 & Sumatera Barat & 1 & 20 & Kalimantan Barat & 3 \\
\hline 4 & Riau & 1 & 21 & Kalimantan Tengah & 1 \\
\hline 5 & Jambi & 2 & 22 & Kalimantan Selatan & - \\
\hline 6 & Sumatera Selatan & 3 & 23 & Kalimantan Timur & 3 \\
\hline 7 & Bengkulu & 3 & 24 & Sulawesi Utara & 2 \\
\hline 8 & Lampung & 5 & 25 & Sulawesi Tengah & 1 \\
\hline 9 & Bangka Belitung & - & 26 & Sulawesi Selatan & 1 \\
\hline 10 & Kep Riau & 1 & 27 & Sulawesi Tenggara & - \\
\hline 11 & DKI Jakarta & 4 & 28 & Gorontalo & 2 \\
\hline 12 & Jawa Barat & 19 & 29 & Sulawesi Barat & 2 \\
\hline 13 & Jawa Tengah & 14 & 30 & Maluku & 1 \\
\hline 14 & D.I Yogyakarta & 2 & 31 & Maluku Utara & - \\
\hline 15 & Jawa Timur & 11 & 32 & Papua & 97 \\
\hline 16 & Banten & 5 & 33 & Papua Barat & \\
\hline 17 & Bali & - & TOTAL & \\
\hline
\end{tabular}

Sumber: diolah dari www.kpu.go.id

Pada pemilu legislatif 2014 pemilihan anggota DPR RI, Provinsi Jawa Barat memperoleh 19 kursi paling banyak sedangkan NTT tidak memperoleh kursi sama sekali. Namun yang menarik di sini adalah walaupun NTT tidak memperoleh kursi di DPR, perolehan kursi di DPRD meningkat, bahkan meningkat 100 persen, di mana pada Pemilu 2009 memperoleh tiga kursi sedangkan Pemilu 2014 meningkat memperoleh 6 kursi. 
Tabel 3. Perempuan Anggota Legislatif DPRD NTT pada Pemilu 2009 dan 2014

\begin{tabular}{|c|c|c|c|c|c|}
\hline No & Provinsi & Tahun 2009 & Tahun 2014 & Jumlah Kursi & Persen \\
\hline 1 & Aceh & 4 & 12 & 81 & Naik \\
\hline 2 & Sumatera Utara & 20 & 13 & 100 & Turun \\
\hline 3 & Sumatera Barat & 7 & 6 & 65 & Turun \\
\hline 4 & Riau & 7 & 18 & 65 & Naik \\
\hline 5 & Jambi & 5 & 6 & 45 & Naik \\
\hline 6 & Sumatera Selatan & 12 & 5 & 45 & Turun \\
\hline 7 & Bengkulu & 7 & 7 & 55 & Tetap \\
\hline 8 & Lampung & 14 & 13 & 75 & Turun \\
\hline 9 & Bangka Belitung & 5 & 8 & 45 & Naik \\
\hline 10 & Kep Riau & 8 & 14 & 85 & Naik \\
\hline 11 & DKI Jakarta & 23 & 22 & 100 & Turun \\
\hline 12 & Jawa Barat & 25 & 19 & 106 & Turun \\
\hline 13 & Jawa Tengah & 21 & 16 & 85 & Turun \\
\hline 14 & D.I Yogyakarta & 11 & 23 & 100 & Naik \\
\hline 15 & Jawa Timur & 18 & 6 & 55 & Turun \\
\hline 16 & Banten & 14 & 13 & 100 & Turun \\
\hline 17 & Bali & 4 & 5 & 55 & Naik \\
\hline 18 & NTB & 6 & 6 & 65 & Tetap \\
\hline 19 & NTT & 3 & 6 & 65 & Naik \\
\hline 20 & Kalimantan Barat & 4 & 7 & 65 & Naik \\
\hline 21 & Kalimantan Tengah & 8 & 10 & 45 & Naik \\
\hline 22 & Kalimantan Selatan & 7 & 7 & 55 & Tetap \\
\hline 23 & Kalimantan Timur & 11 & 6 & 55 & Turun \\
\hline 24 & Sulawesi Utara & 10 & 14 & 45 & Naik \\
\hline 25 & Sulawesi Tengah & 8 & 12 & 45 & Naik \\
\hline 26 & Sulawesi Selatan & 12 & 7 & 45 & Turun \\
\hline 27 & Sulawesi Tenggara & 7 & 8 & 45 & Turun \\
\hline 28 & Gorontalo & 9 & 16 & 85 & Naik \\
\hline 29 & Sulawesi Barat & 4 & 8 & 45 & Naik \\
\hline 30 & Maluku & 14 & 12 & 45 & Turun \\
\hline 31 & Maluku Utara & 4 & 4 & 45 & Tetap \\
\hline 32 & Papua & 4 & 6 & 55 & Naik \\
\hline 33 & Papua Barat & 6 & 1 & 45 & Turun \\
\hline
\end{tabular}

Sumber: PUSKAPOL FISIP UI, 2009 dan 2014 
Tabel 3 menunjukkan keterwakilan perempuan di DPRD Provinsi mengalami peningkatan sebanyak 15 provinsi, empat provinsi tetap dan yang mengalami penurunan sebanyak 14 provinsi. Provinsi dengan keterpilihan perempuan tinggi atau lebih dari seratus persen adalah Aceh, Riau, Kepulauan Riau, D.I Yogyakarta, Nusa Tenggara Timur, Gorontalo dan Sulawesi Barat. Sedangkan provinsi yang jumlahnya tetap adalah Bengkulu, Kalimantan Selatan, Nusa Tenggara Barat dan Maluku Utara.

Untuk itu, keterwakilan perempuan memiliki peran yang sangat penting dalam membawa kepentingan perempuan di dalam kebijakan. Kebutuhan untuk meningkatkan keterwakilan politik perempuan di Indonesia baik di tingkat pusat maupun lokal berpangkal dari suatu kesadaran bahwa semua prioritas dan agenda politik harus dirombak dan semua ini harus didukung oleh elit partai politik dan sistem pemilu yang ramah terhadap perempuan. Meningkatkan keterwakilan politik perempuan berarti juga meningkatkan keefektifan perempuan dalam mempengaruhi keputusan-keputusan politik yang dapat menjamin hak-hak perempuan dan masyarakat luas.

Artikel ini fokus pada perempuan anggota legislatif di DPRD Provinsi NTT periode 2014. Ada sejumlah alasan yang melatarbelakangi dipilihnya perempuan anggota legislatif sebagai studi kasus. Dalam membahas representasi politik di tatanan lokal, hubungan wakil dalam hal ini perempuan anggota legislatif dan konstituen disebabkan adanya kedekatan geografis, kultur, politik dan emosional, serta ruang lingkup aspirasi. Wakil yang berdomisili di daerah pemilihannya memiliki interaksi yang intens dengan konstituennya. Sedangkan aspek ruang lingkup aspirasi, anggota legislatif dapat membawa isu-isu kebijakan yang dekat dengan permasalahan di masyarakat. Selain itu, perempuan NTT mendapatkan tantangan-tantangan yang cukup 
kuat baik dari internal maupun eksternal. Tantangan tersebut akan dijelaskan lebih lanjut dalam sub bab.

\section{PEMBAHASAN: KETERWAKILAN PEREMPUAN}

Esther del Campo (2005, 17-19) dalam Perspective and Limits of the Institutional of the Women's Political Representation, mengidentifikasi beberapa masalah yang dihadapi oleh perempuan dalam usaha mendapatkan akses politik dan jabatan politik berdasarkan pengalaman dari negara-negara di Amerika Latin. Pertama, partai politik dapat diasumsikan sebagai "bottle necks" dimana rekrutmen politik dan seleksi kandidat menyulitkan perempuan. Kedua, perempuan menghadapi keterbatasan akses dan keterbatasan dalam mempengaruhi posisi "high-level" politik manakala adanya keterbatasan otoritas pemerintah. Ketiga, perempuan di partai politik memiliki masalah kelembagaan internal manakala jumlah dan posisi mereka adalah minoritas. Keempat, perempuan sadar kalau keterbatasan kelembagaan mereka karena laki-laki mendominasi setiap diskusi dalam pembuatan dan pemantauan terhadap aturan partai, sementara perempuan hanya mengikuti aturan tersebut. Kelima, perempuan tidak memiliki pengaruh kuat di media. Keenam, resistensi keluarga dan juga lingkungan patrimonial adalah persoalan kultural yang dihadapi perempuan dalam berpolitik. Kondisi yang tidak memungkinkan bagi perempuan ini hanya terjadi di negara-negara Amerika Latin yang memiliki hubungan partron-klien yang kuat tetapi juga hadir di negara-negara Asia, termasuk Indonesia.

Hanna Pitkin (dalam Tremblay 2008, 2-3) mengatakan bahwa konsep representasi politik adalah salah satu kontribusi utama dalam studi keterwakilan perempuan. Perspektif Pitkin in mendefinisikan ada empat dimensi dalam keterwakilan politik yaitu formal, deskriptif, substantif dan simbolis seperti berukut ini: 
Symbolic representation, which embodies an idea or an entity (e.g. a flag a king represents the nation); formal representation, which refers to institutional rules and procedures by which representatives are designed (i.e. the electoral regulation and the voting system); descriptive representation, which refers to the similarities and differences between representatives and the activities of representation (more specifically the responsiveness of the representative to the represented).

Schwindt-Bayer membangun konsep ini dalam sebuah model integrasi tentang keterwakilan perempuan yang dilihat dari tiga cara (Schwindt-Bayer \& Mishler 2005, 214, Schwindt-Bayer 2010, 7). Pertama, representasi formal mempengaruhi representasi deskriptif yakni aturan Pemilu dan regulasi lainnya yang menjelaskan bagaimana pemilu bekerja dan memiliki efek yang kuat terhadap badan perwakilan berdasarkan keragaman ideologi di dalam masyarakat. Kedua, formal dan deskriptif representasi memengaruhi representasi substantif manakala berdasarkan aturan Pemilu, keterwakilan dapat menghasilkan insentif untuk berbuat sesuatu kepada konstituen mereka dengan beragam cara. Hasilnya adalah lembaga legislatif, yang digambarkan sebagai cermin dari keragaman masyarakat dan menawarkan berbagai kesempatan untuk mewakili kepentingan masyarakat. Ketiga, formal deskriptif dan substantif representasi ditransformasikan sebagai cara pemilih melihat pemerintahan. Sebagai contoh kelompok yang tidak terwakili akan memiliki kesempatan besar di dalam pemerintahan jika ada aturan Pemilu yang dapat menentukan bagaimana jenis keterwakilan di lembaga legislatif, jika ada anggota DPR yang berpengaruh dan mewakili kepentingan kelompok tertentu, dan jika lembaga legislatif menyediakan perundang-undangan yang konsisten untuk mempertimbangkan kepentingan kelompok minoritas.

Artikel ini mengaplikasikan pada cara kedua dari konsepnya Schwindt-Bayer yaitu representasi formal dan deskriptif mempengaruhi representasi substantif untuk 
menilai implementasi dari keterwakilan perempuan di parlemen dan makna refleksi untuk isu perempuan. Dalam konteks ini, Tremblay mengilustrasikan pentingnya faktor politik seperti struktur negara, parlemen, kepartaian dan sebagainya, yang mempengaruhi usaha perempuan untuk memperoleh akses kuasa politik (Tremblay 2007, 539). Selain itu, keterwakilan perempuan dalam parlemen dapat dilihat dari perjuangan dan kemampuan kandidat perempuan dalam rangka memenangkan kursi di parlemen untuk mendorong perubahan dalam kebijakan yang berkaitan dengan isu perempuan (Perdana 2014, 77).

\section{DUKUANGAN DEMOKRASI TERHADAP PEREMPUAN}

Demokrasi menjadi sistem politik yang mampu mempertegas identitas perempuan sebagai subjek politik. Rakyat sebagai pemenang kedaulatan harus dilibatkan dalam segala aktivitas politik dan pemerintahan. Oleh sebab itu, perempuan yang merupakan bagian dari rakyat harus dilibatkan dalam partisipasi politik dan pemerintahan.

Definisi demokrasi yang dikemukan oleh David Beetham dan Kevin Boyle yang dikutip oleh Jayadi Nas dalam tulisannya "Demokrasi dan Demokratisasi: Konsep Teori dan Aplikasinya" (Nas 2000, 19-20) mempertegas persoalan mengenai kesetaraan partisipasi politik dalam demokrasi yaitu bahwa demokrasi adalah bagian dari khazanah pembuatan keputusan kolektif. Demokrasi mengejawahtahkan keinginan bahwa keputusan yang memengaruhi perkumpulan secara keseluruhan harus diambil oleh semua anggotanya dan masing-masing anggota harus mempunyai hak yang sama dalam proses pengambilan/pembuatan keputusan. Dengan kata lain, demokrasi menyangkup prinsip kembar kontrol masyarakat atas proses pembuatan keputusan kolektif dan kesamaan hak-hak dalam menjalankan kendali itu. 
Berdasarkan pengertian tersebut, demokrasi menjamin semua anggotanya memiliki hak yang sama dalam mengaspirasikan keinginan. Dengan begitu hak-hak kaum perempuan seharusnya dapat juga mendapat jaminan kesetaraan yang sama dengan laki-laki dalam sistem demokrasi. Hak-hak perempuan dalam kehidupan politik bernegara mendapatkan akses dan kesempatan politik yang setara dalam keterwakilan dalam parlemen.

Siti Zuhro mengatakan bahwa "Di tingkat elit politik, memang memunculkan kader-kader perempuan seperti Puan Maharani maupun Rieke Dyah Pitaloka . Namun, di tingkat daerah belum banyak suara perempuan. Parpol sangat perlu untuk membuat jejaringnya sebagai bentuk pengkaderan untuk merekrut kader-kader perempuan. Jejaring itu bisa dibangun melalui komunitas-komunitas, ormas yang dimiliki PDI Perjuangan, organisasi profesional, hingga bersinergi dengan kampus atau universitas. Dengan kondisi ini, lanjut Siti, elit politik memang harus turun ke bawah untuk menarik partisipasi perempuan di parpol lebih banyak. Kalau elit politik di pusat sudah bergerak, mau tak mau kader di bawahnya akan mengikuti. Bukan lagi menunggu datangnya kader perempuan baru, tapi mencari perempuan yang potensial sesuai dengan parpol, khususnya di kabupaten/kota yang paling minim" (pdiperjuanganjatim.com 2015).

Dan ini menjadi tantangan bagi perempuan di daerah untuk meningkatkan partisipasinya dalam partai politik dan ikut dalam pemilihan umum sehingga dapat meningkatkan representasi perempuan di DPRD Provinsi masing-masing. 
Secara umum, dapat dikatakan bahwa budaya patriarki menjadi penghalang kemajuan perempuan. Budaya patriarki adalah budaya yang menempatkan laki-laki sebagai sentral: pengambil keputusan, pencari nafkah, penerus garis keturunan, benteng perlindungan dan sebagainya. Ketika perempuan diberi akses yang besar untuk sebuah jabatan publik atau pengambil keputusan penting, yang terjadi adalah bukan menguatnya solidaritas melainkan terjadinya rivalitas: perempuan tidak mendukung perempuan, terutama ketika perempuan maju sebagai calon legislatif atau calon kepala daerah.

Representasi perempuan di DPRD Provinsi NTT sifatnya adalah mewakili partai politik, keterwakilan gagasan, keterwakilan kelompok sosial dalam masyarakat. Pada pemilu 2014 representasi perempuan meningkat 100 persen, di mana pada Pemilu 2009 memperoleh tiga kursi sedangkan Pemilu 2014 memperoleh enam kursi (KPU 2014). Peningkatan jumlah ini menghadapi tantangan yang keras dari faktor kultural dan faktor struktural, di mana perempuan NTT masih dianggap sebagai warga kelas dua, perempuan dinilai tidak mempunyai kemampuan untuk masuk ke ranah politik yang hanya diperuntukkan bagi laki-laki. Di samping itu, kurang eksisnya perempuan di partai politik yang banyak didominasi oleh laki-laki. Perempuan NTT yang terlibat dalam partai politik di NTT cukup besar, namun tidak semuannya menduduki posisi yang strategis dalam partai politik (wawancara dengan Ketua Komisi I DPRD Provinsi NTT, Novemver 2017). Pentingnya peran perempuan dalam politik adalah untuk mencapai kesetaraan perempuan dan laki-laki. Perempuan memiliki hak yang sama sebagai warga negara dalam memperjuangkan kepentingan perempuan, bahwa pandangan perempuan harus terlibat dalam proses pengambilan keputusan untuk menghasilkan kebijakan yang memperhatikan kepentingan dan kebutuhan perempuan. 
Pada pemilu tahun 2014, jumlah perempuan anggota legislatif di DPRD Provinsi NTT mengalami peningkatan dari yang sebelumnya pada Pemilu 2009 sebanyak tiga orang. Berikut adalah perempuan anggota legislatif di DPRD Provinsi NTT tahun 2014 disertai dengan nomor urut untuk melihat bahwa elit partai politik menempatkan perempuan pada nomor urut kecil atau nomor urut atas:

Tabel 4. Perempuan Anggota Legistatif Terpilih DPRD Provinsi NTT Tahun 2014

\begin{tabular}{|c|c|c|c|c|}
\hline No & Daerah Pemilihan & Nama & Partai & $\begin{array}{l}\text { No } \\
\text { urut }\end{array}$ \\
\hline 1 & \multirow{3}{*}{$\begin{array}{l}\text { Dapil } 3 \text { (Pulau Sumba yakni Sumba } \\
\text { Timur, Sumba Tengah, Sumba Barat, } \\
\text { dan Sumba Barat Daya) }\end{array}$} & Kristein Samiyati Pati, SP & Nasdem & 8 \\
\hline 2 & & Pdt. Adriana R Kahi Awa Kossi & Golkar & 6 \\
\hline 3 & & Nodu Puga, SpDK (baru) & Gerindra & - \\
\hline 4 & \multirow{2}{*}{$\begin{array}{l}\text { Dapil } 4 \text { (Kab Manggarai, Manggarai } \\
\text { Barat dan Manggarai Timur) }\end{array}$} & Dra. Kristofora Bantang & PDIP & 1 \\
\hline 5 & & Yeni Veronika, SH & PAN & 1 \\
\hline 6 & $\begin{array}{l}\text { Dapil } 5 \text { (Kab Sikka, Ende, Ngada, } \\
\text { Nagekeo) }\end{array}$ & $\begin{array}{l}\text { Angela M. Piwung, } \mathrm{SH} \\
\text { (petahana) }\end{array}$ & Hanura & 3 \\
\hline 7 & $\begin{array}{l}\text { Dapil } 8 \text { (Kab } \text { Timor } \text { Tengah } \\
\text { Selatan/TTS })\end{array}$ & Aleta Kornelia Baun, SH & PKB & 3 \\
\hline
\end{tabular}

Sumber: diolah dari berbagai sumber

Tabel 4 menunjukkan jumlah perempuan yang menjadi anggota legislatif sebanyak tujuh perempuan atau hanya 12 persen, sedangkan laki-laki 88 persen atau 58 kursi dari 65 kursi di DPRD Provinsi. Daerah pemilihan atau dapil di NTT terdiri dari delapan daerah yaitu: (1) Kota Kupang; (2) Kab Kupang. Rote Ndao, Sabu Raijua; (3) Sumba Timur. Sumba Tengah, Sumba Barat dan Sumba Barat Daya; (4) Manggarai, Manggarai Timur dan Manggarai Barat; (5) Ngada, Nagekeo, Ende, Sikka; (6) Flotim, Lembata, Alor; (7) Belu, TTU dan (8). TTS. Dari ke-8 dapil tersebut, perempuan hanya berasal dari 4 dapil sedangkan empat dapil lainnya tidak ada keterwakilan perempuan. 
Keterpilihan perempuan sebagai wakil dalam lembaga legislatif menunjukkan hubungan yang baik antara wakil dan konstituen. Selain itu, ada beberapa perempuan anggota legislatif DPRD Provinsi NTT yang memiliki hubungan keluarga dengan kepala daerah maupun elit partai politik. Di antaranya adalah istri wakil bupati Kabupaten Manggarai yang memperoleh suara paling banyak di antara semua anggota DPRD Provinsi NTT. Juga terdapat istri pengurus Partai Golkar di Kabupaten Sumba Barat Daya. Harus diakui bahwa tujuh perempuan anggota legislatif tersebut merupakan perempuan NTT yang memiliki kemampuan sehingga dapat masuk ke ranah politik. Masing-masing mereka memiliki latar belakang sosial yang berbeda baik dari latar belakang pendidikan, pengalaman kerja serta kapabilitas personal serta ikatan-ikatan sosial lainnya.

Ketujuh perempuan ini memegang gelar sarjana dari berbagai universitas ternama di Indonesia. Selain pendidikan formal, mereka juga pernah mengikuti berbagai pendidikan tambahan dalam bentuk pelatihan di dalam dan di luar negeri. Sebagaian dari mereka berlatar belakang sebagai aktivis, pengusaha, advokat serta pendeta. Angela Piwung dan Aleta Baun adalah dua di antara perempuan anggota legislatif yang memiliki pengalaman di bidang sosial dan lingkungan. Aleta Baun sudah sejak tahun 1990-an aktif memperjuangkan isu lingkungan dengan menolak pembangunan tambang batu bara di Kabupaten TTS dan mendapatkan penghargaan Goldman Enviromental Prize pada 2013 dari Goldman Enviromental Foundation di San Fransisco, California, Amerika Serikat.

Selanjutnya, terkait dengan motivasi yang dimiliki oleh ketujuh perempuan anggota legislatif adalah dorongan dari suami, keluarga dan masyarakat. Pendeta Adriana, Angela Piwung dan Yeni Veronika mendapat dorongan yang penuh dari suami 
dan keluarga besar walaupun mereka bukan berasal dari daerah pemilihan (dapil). Suami-suami yang merupakan putra daerah memberikan dorongan yang besar sehingga ketiga perempuan ini bersedia masuk dalam lembaga legislatif. Selain itu, perempuan ini sudah lama tinggal di dapil sehingga mereka dekat dengan konstituen dan sekaligus memahami isu-isu yang disampaikan oleh konstituen mereka. Berbeda dengan beberapa perempuan anggota legislatif lainnya, Aleta Baun yang merupakan aktivis lingkungan memiliki alasan untuk berpolitik karena refleksi personal dan pernilaian yang mendalam dari hasil pekerja sosial yang telah dilakukan selama bertahun-tahun. Menurutnya, lingkungan dan alam itu dekat dengan perempuan sehingga ia berkewajiban menjaga lingkungan dan alam untuk keberlangsungan anak dan cucu.

\section{HAMBATAN PEREMPUAN DALAM POLITIK DI NTT}

Menurut Anne Philips $(1995,6)$ rendahnya keterwakilan perempuan dalam parlemen terjadi karena faktor struktural dan faktor kultural. Faktor kultural disebabkan oleh stereotype negatif pada perempuan yang berdampak pada pembagian peran dan wilayah aktivitas berdasarkan gender. Sedangkan pada faktor struktural disebabkan adanya dominasi elit laki-laki dalam partai politik dan sistem politik yang tidak efektif untuk meningkatkan keterwakilan perempuan di Parlemen

Faktor kultural dan faktor struktural inilah yang terjadi di NTT. Pada faktor kultural perempuan berperan dalam wilayah domestik (rumah tangga) sehari-hari, sedangkan laki-laki dipercayakan berperan dalam wilayah publik mengurusi urusan politik, sosial, ekonomi dan sebagainya. Perempuan dianggap tidak memiliki kemampuan atau menyalahi norma dan kehendak sosial apabila berperilaku menyimpang dari norma dengan masuk ke dalam ranah politik. Hal inilah yang menyebabkan perempuan tidak memiliki keberanian untuk masuk ke dalam politik. 
Sedangkan pada faktor struktural, laki-laki lebih mendominasi partai politik serta sistem pemilu yang kurang efektif. Idealnya partai politik menjadi akses penting perempuan untuk masuk ke dalam politik menjadi wakil rakyat, namun dari partai politik sendirilah yang menghambat akses perempuan khususnya saat rekrutmen caleg. Prosedur nominasi caleg ditentukan oleh elit partai politik, ditambah lagi dalam struktur pengurusan partai politik banyak di dominasi oleh elit laki-laki. Kalaupun perempuan aktif di dalam partai politik, kecenderungan tidak ditempatkan dalam posisi strategis sebagai pembuat kebijakan.

Peran partai politik sangat diperlukan dalam meningkatkan representasi perempuan di DPRD Provinsi NTT mulai dari prapemilu, pemilu dan pascapemilu. Partai politik melakukan fungsinya dalam rekruitmen caleg perempuan, mendukung perempuan dalam dana pada masa kampanye, menempatkan caleg perempuan pada nomor urut satu atau maksimal nomor urut dua. Dengan terpilihnya perempuan sebagai anggota legislatif, maka perempuan tersebut dapat melakukan rencana aksi dengan fokus pada isu kemiskinan, kesehatan ibu dan anak, pendidikan, tenaga kerja, lingkungan dan pemberdayaan ekonomi perempuan serta isu-isu lain yang berhubungan dengan kepentingan dan kebutuhan perempuan.

\section{PENUTUP}

Keterwakilan perempuan NTT di lembaga legislatif patut diapresiasi, di mana jumlah perempuan mengalami peningkatan yang signifikan pada Pemilu 2014. Tujuh perempuan anggota legislatif di DPRD Provinsi NTT mampu menunjukkan bahwa faktor budaya patriarki yang kuat tidak menghalangi mereka masuk dalam ranah politik untuk mewakili konstituen dari daerah pemilihan masing-masing dan motivasi mereka berpolitik adalah untuk memperjuangkan kepentingan dan kebutuhan konstituen yang 
berkaitan dengan isu perempuan dalam kemiskinan, kesehatan ibu dan anak, pendidikan, tenaga kerja, lingkungan dan pemberdayaan ekonomi perempuan dalam penyusunan kebijakan di parlemen.

Namun demikian, terkait dengan kuota 30 persen masih jauh dari harapan. Untuk itu diperlukan sinergitas dari elit partai politik dan masyarakat sipil (civil society) dalam rangka mendorong dan menempatkan perempuan potensial dalam pencalonan di setiap partai politik.. Dan dapat dipastikan apabila jumlah perempuan semakin banyak di lembaga legislatif maka kebijakan-kebijakan yang dihasilkan adalah untuk kesetaraan dan kesejahteraan perempuan dan laki-laki.

\section{REFERENSI}

Campo, E. d. 2005. Perspective and Limits of the Institutional Aspects of Women's Political Representation. Social Forces, 83 (4), pp. 1697-1725.

Huntington, Samuel P dan Joao M. Nelson. 1977. No Easy Choice: Political Participation in Developing Countries. Cambridge Mass: Harvard University Press.

Komisi Pemilihan Umum. 2014. "Rekapitulasi Perolehan Suara Nasional Pileg 2014" terbit $10 \quad$ Mei $2014 \quad$ diakses dari http://www.kpu.go.id/index.php/pages/detail/2014/282

Lovenduski, Joni dan Azza Karam. 2002. "Perempuan di Parlemen: Membuat Suatu Perbedaan", dalam Julie Ballington, Sakuntala Kadirgamar-Rajasingham, Perempuan di Parlemen: Bukan Sekedar Jumlah (Terjemahan Akmal Syams). International IDEA. Stockholm.

Manzini, Mavivi Myakayakaya. 2002. "Perempuan diberdayakan-Perempuan dalam Parlemen di Afrika Selatan", dalam Julie Ballington, Sakuntala KadirgamarRajasingham, Perempuan di Parlemen: Bukan Sekedar Jumlah (Terjemahan Akmal Syams). International IDEA. Stockholm.

McClosky, Herbert. 1972. Political Participation, International Encyclopedia of the Social Sciences, ed.ke-2. New York: The Macmillan Company.

Nas, Jayadi. 2000. "Demokrasi dan Demoktratisasi: Konsep Teori dan Aplikasinya". WACANA: Jurnal Pemikiran Pascasarjana se-Indonesia. Vol. 1 No. 1, Mei 2005, ISSN: 1858-035. 
PDI Perjuangan Jatim. 2015. "Peneliti: Rekrut Kader Perempuan Melalui Jejaring” terbit 4 April 2015 diakses dari http://pdiperjuangan-jatim.com/peneliti-rekrut-kaderperempuan-melalui-jejaring/

Perdana, Aditya. 2014. "Wajah Aktivis Perempuan dalam Parlemen: Prestasi \& Rekomendasi Politik", dalam Jurnal Perempuan No. 81. Yayasan Jurnal Perempuan. Jakarta.

Philips, Anne. 1995. The Politics of Presence. Oxford: Clarendon Press.

Santi, Budi. 2001. "Kuota Perempuan Parlemen: Jalan Menuju Kesetaraan Politik”, dalam Jurnal Perempuan No. 9. Yayasan Jurnal Perempuan. Jakarta.

Schwindt-Bayer L. A \& Mishler, W. 2005. An Integrated Model of Women's Representation. The Journal of Politics, 67 (2), pp. 407-428.

Schwindt-Bayer, L. A. 2010. Political Power and Women's Representation in Latin America. Oxford: Oxford University Press.

Seda, Francisia. 2002. "Meningkatkan Partisipasi Politik Perempuan: Bukan Sekedar Jumlah Semata, dalam Laporan Konperensi Internasional IDEA. IDEA dan CETRO. Jakarta.

Tremblay, M. 2007. Democracy, Representation and Women: A Comparative Analysis, Democratizition, 14 (4), pp. 533-553.

. 2008. Women and Legislative Representation: Electoral Systems, Political Parties and Sex Quotas. New York: Palgrave Macmillan.

Wardani, Sri Budi Eko, et al. 2013. "Potret Keterpilihan Perempuan di Legislatif pada Pemilu 2009”. Depok: Pusat Kajian Politik FISIP Universitas Indonesia.

2015. "Potret Keterpilihan Anggota Legislatif hasil Pemilu 2014". Depok: Pusat Kajian Politik FISIP Universitas Indonesia.

Yayasan Jurnal Perempuan. 2004. "Modul Perempuan untuk Politik". Jakarta: Yayasan Jurnal Perempuan dan Ausaid. 